The Kinshasa campus contains the Faculté de Droit (Dean: Professor Bayona Ba Meya) and its Centre d'Études de Droit Comparé Africain (CEDCA). The Faculté des Sciences Économiques (Dean: Professor Michel Norro) merges the economics sections of the three former universities and separates economics from the other social sciences; the Institut de Recherches Économiques et Sociaux (IRES) remains but specializes more precisely in economics and development research. Cahiers Économiques et Sociaux will continue to appear as the IRES journal but will deal only with economics and related subjects. The Faculté de Théologie Catholique and its research centre CERA also remain at Kinshasa.

At Kisangani campus (B.P. 2or 2, Kisangani) is the Faculté des Sciences Psychologiques et Pédagogiques. The Dean, Professor (Jean) Bamwisho Mihia, specializes in experimental teaching methods and educational planning and the Vice-Dean, Dr. (Jean) Nkanga KalembaVita in experimental and social psychology. The Secretary, Dr. P. Erny, is an ethnologist and child psychologist. Other members of the faculty specialize in ethnopsychology and in industrial psychology. The faculty has three departments of which one (psychology) is headed by Dr. J. Gaussin, and also a Centre de Recherches Interdisciplinaires pour le Développement de l'Éducation (CRIDE), directed by Dr. Benoit Verhaegen. It publishes a journal Revue Zairoise de Psychologie et Pédagogie. The Protestant Faculty of Theology remains on the Kisangani campus.

\title{
Interdisciplinary Research Program on Angola, Mozambique and Guinea (Bissau)
}

THIs program of interdisciplinary research, supported by the Ford Foundation, is directed by Dr. Gerald J. Bender, Assistant Research Political Scientist, University of California, Los Angeles. It was initiated in May I97I and is concerned with research, data collection and dissemination, and promotion of contact and co-operation between scholars.

The research projects focus on two principal areas: (I) ecological and cultural bases of agricultural economies in Angola, including the Umbundu agricultural ecosystem, and patterns and problems of cattle-raising in Angola; (2) socio-political aspects of Portuguese colonization-the reaction of Africans to a foreign presence, foreign values, and changes which have been introduced and/or projected for the future. The studies cover each colony as a separate entity with its own particular problems, Angola and Mozambique within the larger Southern African bloc, and the larger Portuguese system.

A central repository of data will be created concerning as many aspects of the Portuguese colonies as possible. The data will be in the form of library acquisitions, United Nations Secretariat documents, oral data collected in the colonies, rutal agricultural survey data collected between 1960 and 1970, Angolan archival materials, photographs, and films. Colloquia, institutes and seminars are planned to facilitate co-operation and communication between scholars and disciplines.

Full-time resident UCLA staff, in addition to the Director, are Eduardo Cruz de Carvalho, Associate Research Economist, and three part-time UCLA research assistants. Part-time collaborators include Jorge Vieira da Silva, Associate Research Ecologist (University of Paris VII); Ismael Gaspar-Martins, Assistant Research Economist (United Nations, Research Institute for Social Development); and John Marcum, Research Political Scientist (Provost, Merrill College, University of California, Santa Cruz).

\section{Report of the French Research Team on Linguistics and Literature in the Western Sudan}

THE I970-2 annual report of the Équipe de Recherches Linguistiques et Littéraires au Soudan et au Sahel Occidentaux, E.R.A. 246 ( $s$ avenue de la Bordonnais, Paris VIIe) is now available. 